\title{
Preliminary analysis of linear and angular kinetic parameters of the gait of
}

\section{individuals with cerebral palsy}

\author{
Análise preliminar dos parâmetros cinéticos lineares e angulares da marcha dos indivíduos com \\ paralisia cerebral
}

Análisis preliminar de los parámetros cinéticos lineales y angulares de la marcha de individuos con parálisis cerebral

\author{
Janaína de Oliveira Rodrigues \\ ORCID: https://orcid.org/0000-0003-4175-723X \\ Universidade Federal de Uberlândia, Brazil \\ E-mail: janainaoliveirarodriguesl@gmail.com \\ Angela Abreu Rosa de Sá \\ ORCID: https://orcid.org/0000-0002-1818-8270 \\ Universidade Federal de Uberlândia, Brazil \\ E-mail: angelaabreu@gmail.com \\ Deny Gomes Freitas \\ ORCID: https://orcid.org/0000-0001-7307-4850 \\ Universidade Federal de Uberlândia, Brazil \\ E-mail: denyfreitas@hotmail.com \\ Eduardo Lázaro Martins Naves \\ ORCID: https://orcid.org/0000-0003-4175-723X \\ Universidade Federal de Uberlândia, Brazil \\ E-mail: eduardonaves@ufu.br
}

\begin{abstract}
Normal gait patterns allow the identification of the normal movement pattern, such as the gait of people with cerebral palsy. Paralympic classification systems aim to include the participation in sports of people with cerebral palsy, minimizing the impact of the injury on the result of the competition. In this context, this study aims to investigate, functionally, the linear and angular kinetic parameters of gait in individuals with cerebral palsy. 15 participants with cerebral palsy were classified into three groups according to the classification of the International Paralympic Committee: 1) T35- diplegic; 2) T36- athetoid ataxic; 3) T37- hemiplegic. For data acquisition, we used a motion capture system in 3 dimensions. The results showed significant differences between the three groups in some linear and angular gait variables, corroborating the qualitative classification process already used by the International Paralympics Committee. In addition, we identified the existence of people with different levels of cerebral palsy within a single functional class of International Paralympics Committee. We found significant differences in some linear and angular gait variables among the classes T35, T36 e T37, which suggest "subgroups" inside each category, and this would prevent a athlete from competing on equal terms with the other competitors.
\end{abstract}

Keywords: Paralysis; Gait Analysis; Kinematics; Athletes.

\begin{abstract}
Resumo
Os padrões normais de marcha permitem a identificação do padrão normal de movimento, tal como a marcha de pessoas com paralisia cerebral. Os sistemas de classificação paraolímpica visam incluir a participação em desportos de pessoas com paralisia cerebral, minimizando o impacto da lesão no resultado da competição. Neste contexto, este estudo visa investigar, funcionalmente, os parâmetros cinéticos lineares e angulares da marcha em indivíduos com paralisia cerebral. 15 participantes com paralisia cerebral foram classificados em três grupos, de acordo com a classificação do Comité Paraolímpico Internacional: 1) T35- diplégico; 2) T36- atetóide ataxico; 3) T37- hemiplégico. Para a aquisição de dados, utilizámos um sistema de captura de movimento em 3 dimensões. Os resultados mostraram diferenças significativas entre os três grupos em algumas variáveis de marcha linear e angular, corroborando o processo de classificação qualitativa já utilizado pelo Comité Paraolímpico Internacional. Além disso, identificamos a existência de pessoas com diferentes níveis de paralisia cerebral dentro de uma única classe funcional do Comité Paraolímpico Internacional. Encontramos diferenças significativas em algumas variáveis de marcha linear e angular entre as classes T35, T36 e T37, que sugerem "subgrupos" dentro de cada categoria, e isto impediria um atleta de competir em condições de igualdade com os outros concorrentes.
\end{abstract}

Palavras-chave: Paralisia; Análise da Marcha; Cinemática; Atletas. 


\section{Resumen}

Los patrones de marcha normales permiten identificar el patrón de movimiento normal, como la marcha de las personas con parálisis cerebral. Los sistemas de clasificación paralímpica pretenden incluir la participación en deportes de personas con parálisis cerebral, minimizando el impacto de la lesión en el resultado de la competición. En este contexto, este estudio pretende investigar, funcionalmente, los parámetros cinéticos lineales y angulares de la marcha en individuos con parálisis cerebral. 15 participantes con parálisis cerebral fueron clasificados en tres grupos según la clasificación del Comité Paralímpico Internacional 1) T35-diplejía; 2) T36-atáxica; 3) T37-hemiplejía. Para la adquisición de datos, se utilizó un sistema de captura de movimiento en 3 dimensiones. Los resultados mostraron diferencias significativas entre los tres grupos en algunas variables de la marcha lineal y angular, corroborando el proceso de clasificación cualitativa ya utilizado por el Comité Paralímpico Internacional. Además, identificamos la existencia de personas con diferentes niveles de parálisis cerebral dentro de una misma clase funcional del Comité Paralímpico Internacional. Encontramos diferencias significativas en algunas variables de la marcha lineal y angular entre las clases T35, T36 y T37, lo que sugiere la existencia de "subgrupos" dentro de cada categoría, lo que impediría a un atleta competir en igualdad de condiciones con los demás competidores.
\end{abstract}

Palabras clave: Parálisis; Análisis de la Marcha; Cinemático; Atletas.

\title{
1. Introduction
}

Human locomotion is performed in bipedal posture and the main motion function is to promote body displacement by advancing a lower limb, while the other acts in support of body weight (Anderson \& Williams, 2022; G.Feldman et al., 2021; Sutherland \& Valencia, 1992). Important research on human movement took place after the Second World War, when studies determined normal and pathological gait patterns. (Davis, 1997; Ferrazzoli et al., 2022; Filho \& Santos, 2008; Jun et al., 2020). In order to identify pathological gait, it is essential to have a good knowledge of the biomechanics of normal human gait. For this type of evaluation, the analysis of linear and angular kinetic parameters of gait is used (Dorofeev et al., 2021; Mundt et al., 2021; Sorsdahl et al., 2008; Stolze et al., 1998).

People with cerebral palsy (CP) are those with impaired neurological systems, in different locations and levels of involvement; that trigger neuromotor disorders that can affect upright posture, balance and the ability to walk (Bax, 2005; Damiano et al., 2021; Peixoto et al., 2021; Peterson \& Hurvitz, 2021). However, there are different types of injuries and levels that determine gait patterns. And to analyze the gait of people with $\mathrm{CP}$, it is necessary to perform a functional classification to group them according to the levels and types of injuries.

The International Paralympic Committee (IPC) has a functional athletics classification guide for people with various motor and intellectual disabilities, including CP. The functional classification of the IPC allows the grouping process, in relation to the athletes' morphological, clinical and physical skills. (Thompson \& Vanlandewijck, 2020; Tweedy \& Bourke, 2009). However, most studies use only the IPC classification, without considering possible biomechanical differences in gait. It is important to highlight that biomechanical differences can help to understand the limitations of mobility and, consequently, contribute to the development of specific treatments to improve the motor function of people with CP.

In this context, this study aims to quantify and compare the linear and angular kinetic alterations of human gait of groups of people belonging to CP classes (T35, T36 and T37), according to the IPC guide. Our hypothesis was that it could have significant differences in gait variables between classes T35, T36 and T37; which would prevent an athlete from competing on an equal footing with the other competitors.

\section{Methodology}

The eligibility criteria for this study were: 1) Presenting cerebral palsy with clinical diagnosis; 2) Have the ability to walk independently, without assistance; 3) Have adequate cognition to understand the tasks; 4) Not having other physical and mental disabilities that hinder the walking process. 
Fifteen participants with CP (10 male and 5 female), aged from 12 to 23 years old, were selected. The participants were evaluated by an evaluator registered by the IPC and then classified into three groups: a) T35 - diplegic CP (n=5); b) T36 - athetoid and ataxic CP (n=5); c) T37 - hemiplegic CP (n=5).

\section{Anthropometric evaluation}

Participants wore bathing suits and no shoes. We collected the following anthropometric data: body mass (kg), height (m), trunk length $(\mathrm{m})$ and leg length $(\mathrm{m})$. Body mass was measured on a MIC 200 model scale (Micheletti ${ }^{\circledR}$ ), with the accuracy of $0.05 \mathrm{~kg}$. Height and trunk length was checked by stadiometer (Sanny ${ }^{\circledR}$ ), with the accuracy $0.001 \mathrm{~m}$. Body length was measured with participants sitting on the floor with their spine upright against the wall. Height was measured with the participant standing. The length of the lower limbs was defined as being the length of the trunk minus the height.

\section{$\underline{\text { Kinematics evaluation }}$}

Reflective markers $1.5 \mathrm{~cm}$ in diameter were placed on specific regions of the body according to the guidelines of the ARENA Motion Capture TM software. Then, participants were positioned in a T position, standing, with abducted shoulders, extended elbows, thighs abducted and looking at the horizon for markers recognition by eight infrared cameras (Optitrack Flex,model V100R2 - Natural Point, US - sample rate of $100 \mathrm{~Hz})$ at the center of the gait assessment area $(3.00 \mathrm{~m}$ long, $2.00 \mathrm{~m}$ wide and $2.50 \mathrm{~m}$ high). Each participant was evaluated three times. Each time, the participant was asked to walk four times in an area delimited at volitional speed, which corresponds to a walk of approximately thirty seconds.

\section{$\underline{\text { Variables }}$}

After data acquisition, the trajectories of the markers were exported to the C3D Analysis software format, developed on the LabVIEW TM. In the C3D Analysis software, the graphic regions were manually defined, using the cursor, to calculate linear kinetic variables (Table 1).

Table 1 - Linear variables.

\begin{tabular}{lll}
\hline Variable & Acronym & Measure unit \\
\hline Speed & Speed & $\mathrm{m} / \mathrm{s}$ \\
Stride Length Left & SLL & $\mathrm{M}$ \\
Stride Length Right & SLR & $\mathrm{M}$ \\
Stride Length Left- Plegic & SLL-P & $\mathrm{M}$ \\
Stride Length Right - Plegic & SLR-P & $\mathrm{M}$ \\
Width & Width & $\mathrm{M}$ \\
Cadence & Cadence & steps/min \\
Single Left Support & SLS & $\%$ \\
Single Right Support & SRS & $\%$ \\
Single Left Support - Plegic & SLS-P & $\%$ \\
Single Right Support - Plegic & SRS-P & $\%$ \\
Double Support & DS & $\%$ \\
Left Balance & LB & $\%$ \\
Right Balance & RB & $\%$ \\
Left balance- Plegic & LB-P & $\%$ \\
Right balance- Plegic & RB-P & $\%$ \\
\hline
\end{tabular}

Source: Elaborated by the authors (2022). 
For the angular analysis (Table 2), the images of each phase of the recorded gait were used in relation to the same frames analyzed by the C3D analysis. These images were transferred to the CorelDRAW12 software, where the angles of the hip, knee and ankle (sagittal plane) and the angles of the trunk and hip (frontal plane) were calculated.

Table 2 - Angular variables.

\begin{tabular}{lcc}
\hline Variable & Acronym & Measure Unit \\
\hline Right Hip flexion & RHF & $\left(^{\circ}\right)$ \\
Right hip flexion- Plegic & RHF-P & $\left(^{\circ}\right)$ \\
Left Hip Flexion & LHF & $\left(^{\circ}\right)$ \\
Left hip flexion-Plegic & LHF-P & $\left(^{\circ}\right)$ \\
Right knee flexion & RKF & $\left(^{\circ}\right)$ \\
Right knee flexion-Plegic & RKF-P & $\left(^{\circ}\right)$ \\
Left knee flexion & LKF & $\left(^{\circ}\right)$ \\
Left knee flexion-Plegic & LKF-P & $\left(^{\circ}\right)$ \\
Right dorsiflexion & RDF & $\left(^{\circ}\right)$ \\
Plegic right dorsiflexion & RDF-P & $\left(^{\circ}\right)$ \\
Left Dorsiflexion & LDF & $\left(^{\circ}\right)$ \\
Left dorsiflexion-Plegic & LDF-P & $\left(^{\circ}\right)$ \\
Right support hip inclination & RSHI & $\left(^{\circ}\right)$ \\
Right support hip inclination-Plegic & RSHI-P & $\left(^{\circ}\right)$ \\
Left support hip inclination & LSHI & $\left(^{\circ}\right)$ \\
Left support hip inclination-Plegic & LSHI-P & $\left(^{\circ}\right)$ \\
Right support trunk inclination & RSTI & $\left(^{\circ}\right)$ \\
Right support trunk inclination- Plegic & RSTI-P & $\left(^{\circ}\right)$ \\
Left support trunk inclination & LSTI & $\left(^{\circ}\right)$ \\
Left support trunk inclination- Plegic & LSTI-P & $\left(^{\circ}\right)$ \\
\hline
\end{tabular}

Source: Elaborated by the authors (2022).

\section{Statistical Analysis}

We used the software SPSS 20.0 and Sisvar 4.3 for statistical analysis. Shapiro-Wilk was used to analyze the normal distribution. As the variables had a normal distribution, analysis of variance (ANOVA) was applied with Tukey's post hoc test to detect differences between groups. Significance levels were set for $\mathrm{p} \leq 0.05$.

\section{Results}

Significant differences in linear variables were found for SLR, SLL, SLS, SRS, LB-P and RB-P (Table 3). For SLR, T37 group presented higher average values than other groups $(0.489 \mathrm{~m})$. For stride length, T36 group showed higher average values than other groups $(0.235 \mathrm{~m})$. For SRS and SLS, T37 group presented higher average values than other groups $(0.42$ and $0.433 \mathrm{~m}$, respectively). For RB-P and LB-P,T37 group also presented higher average values compared to other groups $(0.433$ and $0.42 \mathrm{~m}$, respectively). 
Table 3 - Analysis of variance (ANOVA) for linear variables of the groups T35, T36 and T37 classified according to the criteria of the IPC.

\begin{tabular}{lcccc}
\hline GROUPS & $\mathrm{T} 35$ & $\mathrm{~T} 36$ & $\mathrm{~T} 37$ & p \\
\hline Speed (m/s) & $\mu \pm S D$ & $\mu \pm S D$ & $\mu \pm S D$ & \\
SLL (m) & $0.564 \pm 0.185$ & $0.595 \pm 0.145$ & $0.655 \pm 0.149$ & 0.17 \\
SLR (m) & $0.372 \pm 0.158$ & $0.381 \pm 0.161$ & $0.417 \pm 0.099$ & 0.22 \\
SLL-P (m) & $0.365 \pm 0.079$ & $0.366 \pm 0.075$ & $0.489 \pm 0.049$ & 0.00 \\
SLR-P (m) & $0.372 \pm 0.158$ & $0.381 \pm 0.161$ & $0.439 \pm 0.042$ & 0.13 \\
Width (m) & $0.365 \pm 0.079$ & $0.366 \pm 0.075$ & $0.376 \pm 0.065$ & 0.91 \\
Cadence & $0.17 \pm 0.055$ & $0.235 \pm 0.07$ & $0.127 \pm 0.045$ & 0.00 \\
(steps/min) & $90.8 \pm 16.4$ & $95.6 \pm 13.6$ & $98.5 \pm 11.9$ & 0.21 \\
SLS (\%) & & & & \\
SRS (\%) & $36.3 \pm 5.0$ & $38.7 \pm 6.4$ & $43.3 \pm 3.8$ & 0.00 \\
SLS-P (\%) & $33.2 \pm 6.3$ & $36.1 \pm 6.3$ & $42.0 \pm 3.4$ & 0.00 \\
SRS-P (\%) & $36.3 \pm 5.0$ & $38.7 \pm 6.4$ & $36.3 \pm 2.9$ & 0.44 \\
Double Support & $33.2 \pm 6.3$ & $36.1 \pm 6.3$ & $34.3 \pm 4.5$ & 0.46 \\
(\%) & $24.2 \pm 5.0$ & $24.8 \pm 6.9$ & $23.0 \pm 5.4$ & 0.61 \\
LB (\%) & & & & \\
RB (\%) & $33.2 \pm 6.3$ & $36.1 \pm 6.3$ & $34.3 \pm 4.5$ & 0.46 \\
LB-P (\%) & $36.3 \pm 5.0$ & $38.7 \pm 6.4$ & $36.3 \pm 2.9$ & 0.44 \\
RB-P(\%) & $33.2 \pm 6.3$ & $36.1 \pm 6.3$ & $42.0 \pm 3.4$ & 0.00 \\
\hline
\end{tabular}

Source: Elaborated by the authors (2022).

For slope angular variables, larger number of significant differences was found, which might help characterizing motion of each group (Table 4). At initial stance phase, for LSTI, the T35 group presented significant difference for inclination to the left $\left(5.8^{\circ}\right)$ comparing to T36 and T37 groups, which presented slopes to the right $\left(-0.2^{\circ}\right.$ and $-0.4^{\circ}$, respectively). For LSTI-P, T35 and T37 group presented significant difference for inclination to the left $\left(5.8^{\circ}\right.$ and $2.0^{\circ}$, respectively), comparing toT36 group.

During final stance phase, for RSHI the T35 group presented inclination to the right $\left(-4.2^{\circ}\right)$ differentiating from T36 and T37groups, which presented inclination to the left $\left(1.7^{\circ}\right.$ and $2.3^{\circ}$, respectively). For LSTI, the T35 group presented higher inclination angle to the left $\left(10.6^{\circ}\right)$ and $\mathrm{T} 37$ group presented inclination to the right $\left(-1.2^{\circ}\right)$. T36 group presented no statistical differences. For LSTI-P, T37 group showed lower inclination to the left angle $\left(1.0^{\circ}\right)$, as well as other groups, but remained statistically different from T35group. At middle balance, RSTI and RSTI-P showed significant difference between T35 (12.0 $\left.{ }^{\circ}\right)$ and T37 $\left(0.8^{\circ}\right)$ groups. T36 group did not differ from other groups. 
Table 4 - Analysis of variance (ANOVA) of the kinematic variables of angular tilt of the hip and trunk, in the phases of support (initial and final) and balance (middle) for T35, T36 and T37 groups classified according to the criteria of the IPC.

\begin{tabular}{|c|c|c|c|c|c|c|c|c|c|c|c|c|}
\hline & \multicolumn{3}{|c|}{ Initial Support } & & \multicolumn{3}{|c|}{ Final Support } & & \multicolumn{3}{|c|}{ Middle Balance } & \\
\hline & \multicolumn{12}{|c|}{ Groups } \\
\hline Variables & T35 & T36 & T37 & p & T35 & T36 & T37 & $\mathbf{p}$ & T35 & T36 & T37 & $\mathbf{p}$ \\
\hline & $\mu \pm S D$ & $\mu \pm S D$ & $\mu \pm S D$ & & $\mu \pm S D$ & $\mu \pm S D$ & $\mu \pm S D$ & & $\mu \pm S D$ & $\mu \pm S D$ & $\mu \pm S D$ & \\
\hline RSHI ( $\left.{ }^{\circ}\right)$ & $-1.6 \pm 2.0$ & $-1.0 \pm 4.7$ & $1.6 \pm 1.1$ & 0.38 & $-4.2 \pm 1.7$ & $1.7 \pm 1.8$ & $2.3 \pm 3.2$ & 0.00 & $0.6 \pm 6.0$ & $-1.0 \pm 2.9$ & $2.0 \pm 1.0$ & 0.67 \\
\hline RSHI-P $\left(^{\circ}\right)$ & $-1.6 \pm 2.0$ & $-1.0 \pm 4.7$ & $-1.7 \pm 4.3$ & 0.95 & $-4.2 \pm 1.7$ & $1.7 \pm 1.8$ & $-1.2 \pm 6.4$ & 0.08 & $0.6 \pm 6.0$ & $-1.0 \pm 2.9$ & $-1.4 \pm 3.0$ & 0.70 \\
\hline LSHI $\left(^{\circ}\right)$ & $1.2 \pm 4.2$ & $1.2 \pm 3.2$ & $-0.7 \pm 3.5$ & 0.60 & $2.6 \pm 5.8$ & $-0.2 \pm 4.1$ & $-2.8 \pm 4.9$ & 0.20 & $-2.4 \pm 4.3$ & $1.2 \pm 3.9$ & $-1.7 \pm 4.0$ & 0.42 \\
\hline LSHI-P $\left({ }^{\circ}\right)$ & $1.2 \pm 4.2$ & $1.2 \pm 3.2$ & $1.6 \pm 1.1$ & 0.98 & $2.6 \pm 5.8$ & $-0.2 \pm 4.1$ & $2.0 \pm 1.0$ & 0.65 & $-2.4 \pm 4.3$ & $1.2 \pm 3.9$ & $2.3 \pm 4.1$ & 0.27 \\
\hline RSTI $\left(^{\circ}\right)$ & $-2.8 \pm 4.9$ & $-0.5 \pm 4.5$ & $3.6 \pm 1.5$ & 0.40 & $-4.0 \pm 8.6$ & $-5.5 \pm 2.5$ & $3.3 \pm 2.0$ & 0.18 & $12.0 \pm 5.3$ & $3.7 \pm 6.3$ & $0.6 \pm 3.2$ & 0.03 \\
\hline RSTI-P $\left(^{\circ}\right)$ & $-2.8 \pm 4.9$ & $-0.5 \pm 4.5$ & $-1.4 \pm 6.1$ & 0.12 & $-4.0 \pm 8.6$ & $-5.5 \pm 2.5$ & $-5.2 \pm 8.0$ & 0.94 & $12.0 \pm 5.3$ & $3.7 \pm 6.3$ & $0.8 \pm 6.3$ & 0.02 \\
\hline $\operatorname{LSTI}\left({ }^{\circ}\right)$ & $5.8 \pm 3.8$ & $-0.2 \pm 2.3$ & $-0.4 \pm 5.0$ & 0.05 & $10.6 \pm 3.4$ & $4.2 \pm 3.5$ & $-1.2 \pm 6.4$ & 0.02 & $-4.0 \pm 8.6$ & $-3.7 \pm 2.6$ & $-4.8 \pm 7.0$ & 0.96 \\
\hline $\operatorname{LSTI-P}\left({ }^{\circ}\right)$ & $5.8 \pm 3.8$ & $-0.2 \pm 2.3$ & $2.0 \pm 2.0$ & 0.04 & $10.6 \pm 3.4$ & $4.2 \pm 3.5$ & $1.0 \pm 3.6$ & 0.00 & $-4.0 \pm 8.6$ & $-3.7 \pm 2.6$ & $4.3 \pm 1.5$ & 0.17 \\
\hline
\end{tabular}

Source: Elaborated by the authors (2022).

In sagittal plane, few significant differences were found for angular variables (Table 5). At initial support stage, there was no difference between LHF and LHF-P data. T35 group presented greatest flexion angle $\left(22.4^{\circ}\right)$ and T37group lowest flexion angles ( $16.8^{\circ}$ and $15.6^{\circ}$, respectively). Significant differences were found at middle stance phase. For RDF, T35 group showed the highest dorsiflexion angle $\left(14.4^{\circ}\right)$ and T36 group showed the lowest dorsiflexion angle $\left(5.5^{\circ}\right)$, whereas T37 group presented no difference comparing to T36 group $\left(6.6^{\circ}\right)$. For RDF, T37-P group showed no significant difference compared to T35 and T36.

Table 5 - Analysis of variance (ANOVA) of the kinematic variables of angular flexion-extension of the hip, knee and ankles support phases (initial, middle and final), for T35, T36 and T37 groups classified according with the criteria of the IPC.

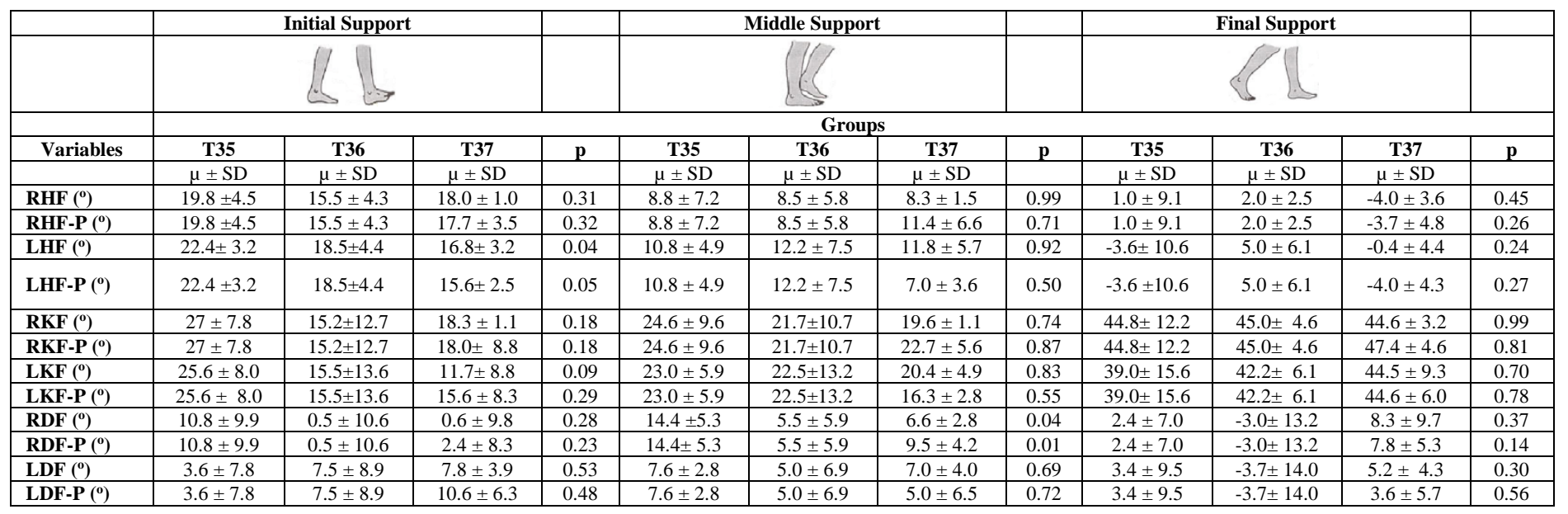

Source: Elaborated by the authors (2022).

\section{Discussion}

This study aimed to identify changes in kinematic parameters of gait in people with CP who are classified as T35, T36 and T37, according to IPC classification manual. IPC is pioneer in using functional assessment in sports, since clinical 
assessments as Gross Motor Function Classification System were more commonly used in the past (Dini \& David, 2009; Kwon et al., 2011; Matsuno et al., 2010; Prosser et al., 2010; Zonta et al., 2010) .

Linear variables are important in gait analysis. Stride length related variables showed greater differences in both paretic and non-paretic sides in T37 group, mainly because healthy hemispheres help the affected side with longer support duration, providing increased stride length. The step width (segment connecting the middle points between markers in heel and in the tip of toes) presented significant differences. We found greater average values (T35 group $=0.17 \mathrm{~m}$; T36group $=0.235$ $\mathrm{m}$, and; T37 group $=0.127 \mathrm{~m}$ ) compared to healthy participants (from 0.05 to $0.1 \mathrm{~m}$ ), as published by (Magee, 2005; Perry, 2005; Stolze et al., 1997). This means that people with CP need a larger base to achieve body stability.

In addition, linear time variables were quantified as percentage of total gait cycle duration. For these variables, T37 group had longer SRS and LB-P durations (42.0\%) as well as longer SLS and RB-P durations (43.3\%). This difference occurs mainly because hemiplegic people use more the unaffected hemisphere while walking and, hence, present a deficit in body alignment, which makes the weight transfer to the affected side difficult. Furthermore, lower muscle activation in performing hip and knee flexion/extension during the swing of the paretic side results in slower movements and longer support over unaffected side (Dini \& David, 2009). No significant difference was found for T35 or T36 groups. This shows greater balance, especially in body weight transfer during displacement. These groups also showed small changes in stance and swing durations resembling healthy people measures(O’Sullivan \& Schmitz, 2010; Stolze et al., 1997).

Regarding flexion-extension angular data, few variables showed significant differences. During initial stance, T35 group showed higher values of hip flexion (similar to healthy people values $-20.0^{\circ}$ ), when compared to T36 and T37 groups, which showed inadequate hip flexion due to poor active muscle control during initial balance.

Higher values of knee flexion were found for T35 groups due to insufficient quadriceps and triceps muscles activation(Hebert et al., 2003) compared to the other groups. Average right knee flexion and dorsiflexion were larger than the left side, possibly indicating higher motor dysfunction in brain's left side. According to (Magee, 2005; O’Sullivan \& Schmitz, 2010), knee flexion in initial stance normally varies from $0^{\circ}$ to $15^{\circ}$, similar to what found for T36 group. The T37 group presented increased values in right side and normal values in the left side, independently of the affected side, indicating muscle activation deficiency during initial stance.

For dorsiflexion, T35 group showed excessive values on the right side, mainly due to an unstable position caused by forward displacement of the heel. But, to the left side, slight dorsiflexion was observed. T36 group showed minimal dorsiflexion to the right side $\left(0.5^{\circ}\right)$, and considerable dorsiflexion to the left side $\left(7.5^{\circ}\right)$, which may demonstrate athetoid and ataxic actions during support. T37 group presented higher dorsiflexion angles for the paretic sides than for non paretic. And also, no difference was found between groups for hip flexion in middle stance phase, ranging from $8.0^{\circ}$ to $12.0^{\circ}$ (closely to normal values). All groups presented similar increased values of knee flexion, suggesting possible hamstring muscles hyperactivity caused by spasticity, which also leads to increased dorsiflexion. It occurs due to the advance of tibia over the foot, and it was confirmed in all groups, with higher values for T35 group. However, spasticity and/or shortening of hamstring muscles can limit knee extension during gait.

Furthermore, during final stance phase, some hip joint differences were found. Right side flexion and left side extension were found four T35 group, while T36 group presented flexion for both sides and T37 group showed extension for both paretic and not paretic sides, but lower than normal values $\left(10^{\circ}\right.$ to $\left.20^{\circ}\right)$ for healthy people(Magee, 2005). The importance of knee flexion during final stance phase is the continued hamstrings involvement, as well as soleus weakness or inefficiency to control tibia, with values ranging from $39.0^{\circ}$ to $45.0^{\circ}$, with no difference between groups. 
According to (Magee, 2005; O'Sullivan \& Schmitz, 2010), in the stance phase occurs plantar flexion of up to $20^{\circ}$ for healthy people. However, T36 group showed small plantar flexion, and T35 and T37 showed dorsiflexion. These actions can be associated with triceps surae weakness.

Moreover, during the middle balance phase, a small hip flexion was found in all groups consistent with hip stiffness, restricting member advance and preventing step increments. This occurs due to weakness or incapacity to activate the hip flexors muscles, leading to greater knee flexion to proceed(Magee, 2005; O’Sullivan \& Schmitz, 2010). In addition, all groups showed $50.0^{\circ}$ to $60.0^{\circ}$ of knee flexion during middle balance phase. Greatest group averages were RKF-P and LKF-P to T37 group, which were also larger in paretic side. This flexion is due to both deficient hip flexion and continued participation of the hamstrings, which continues in the balance phase. Although some authors reported the existence of maintained plantar flexion throughout balance phase in people with CP (Filho \& Santos, 2008), all groups presented dorsiflexion, due to lack of triceps surae activation.

We also analyzed the angular variables of trunk and hips lateral inclination. During initial stance phase, T35 group showed ipsilateral inclination, to the supporting side. For instance, when initial stance was performed with the right foot, hip and trunk laterally inclined to the right and when the left foot rested, hips and trunk inclined to the left. According to Perry(Perry, 2005), trunk inclination to the support member side is expected. However, the alignment of the hip at initial contact depends on the distance between supports, thus the hip may incline or not. Also, little trunk inclinations to the right happened independent of the supporting side in T36 group. Hip inclination followed the support side, as T35 group. For T37 group, lateral hip and trunk inclination occurred with support in non-paretic side during initial stance phase. Ipsilateral trunk and hip inclinations occurred with support in the paretic side. During final stance phase, hip and trunk inclined to the right while in right side support for T35 group, and they inclined to the left while in left side support, like in initial support featuring the Trendelenburg gait (Hebert et al., 2003).

Dynamics between trunk and hip for T36 group is similar to that of healthy people. When supported in the right side, ipsilateral trunk inclination and lateral hip inclination occurred - and the same was observed to the opposite side. In addition, when supported in non-paretic side, contralateral trunk and hip inclination occurred for T37 group. And also, when supported in paretic side, ipsilateraltrunk and hip inclination occurred, as observed for T35 group. However, this group presented inclination to the paretic side in final stance phase. Moreover, paretic sides of T35 and T37 groups showed ipsilateral hip inclination, due the gastrocnemius and soleus muscles weakness to support weight over raised heel, or even lack of heel rise. And for T37 group, lateral trunk and hip inclinations to the paretic side were observed. This occurs because hemiplegic people have impaired body image, with poor perception of their body weight line.

And regarding to support phase, trunk displacement aims to restore balance, which is a useful strategy to compensate inadequate hip abductors' function. Lateral inclination varies according to hip musculature weakness (Perry, 2005). Contralateral trunk inclination represents deficient compensation to disturbed balance.

Finally, during middle swing, for T35 group, when right leg was in swing, contralateral trunk and hips inclinations occurred, and vice versa. In every gait phase, trunk and hip inclinations were similar, probably due to higher step widths. In addition, for T36 group, when right leg was in swing, contralateral trunk inclination and ipsilateral hip inclination occurred, and vice versa. Hip inclination is mainly due to abductor muscles weakness of the support limb leading to a stereotyped hip fall, which is counter balanced by raising the balance limb.

\section{Conclusion}

The classification of participants with Cerebral Palsy according to IPC criteria enables to identify distinct gait kinematic parameters among them. However, we found some possible failures in IPC classification standards, since there is no 
subdivision regarding lesion severity among classes. For example, among diplegic class T35, middle, moderate and severe disabilities are equally classified. The same occur for classes T36 (athetosis and ataxia) and T37 (hemiplegic). Thus, it is difficult to standardize gait patterns to each group.

The results support the differentiation into three classes (T35, T36 and T37) based on the qualitative criteria of the IPC and the knowledge and expertise of the evaluator. In addition, we found "subgroups" inside each category. For instance, people with different capabilities were classified in the same category. These findings answer our initial hypothesis: yes, it is possible to have significant differences in some linear and angular gait variables among the classes T35, T36 e T37; which would prevent the athlete from competing on equal terms with the other competitors.

As future work, we suggest an analysis with a larger group of participants within each class. Moreover, further analyses are needed to propose possible subgroups within classes T35, T36 and T37. Finally, the use of electromyography during data collection would be interesting and valuable for analyzing muscle actions during the gait.

\section{Ethics approval and consent to participate}

- This study was approved by the Ethics Committee of Federal University of Uberlandia - Brazil, ID CAAE number 570/10;

- Informed Consent Document was signed by participants and approved by the Ethics Committee from Federal University of Uberlandia - Brazil, ID CAAE number 570/10.

\section{Acknowledgments}

This study was financed in part by the Coordenação de Aperfeiçoamento de Pessoal de Nível Superior - Brasil (CAPES). Finance Code 001.

\section{References}

Anderson, D. I., \& Williams, A. M. (2022). Individual differences in motor skill learning. Human Movement Science, 81. https://doi.org/10.1016/j.humov.2021.102904

Bax, M. e. A. (2005). Proposed definition and classification of cerebral palsy. Medicine\&Child Neurology, 47(8).

Damiano, D. L., Longo, E., Campos, A. C. de, Forssberg, H., \& Rauch, A. (2021). Systematic Review of Clinical Guidelines Related to Care of Individuals With Cerebral Palsy as Part of the World Health Organization Efforts to Develop a Global Package of Interventions for Rehabilitation. Archives of Physical Medicine and Rehabilitation, 102, 1-11. https://doi.org/https://doi.org/10.1016/j.apmr.2020.11.015

Davis, B. d. (1997). Reflections on clinical gait analysis. Journal of Electromyography and Kinesiology, 7(4), 251-257.

Dini, P. D. ., \& David, A. C. (2009). Repetibilidade dos parâmetros espaço-temporais da marcha: comparação entre crianças normais e com paralisia cerebral do tipo hemiplegia espástica. Revista Brasileira de Fisioterapia, 13, 215-222.

Dorofeev, N. V., Grecheneva, A. ., \& Buzhinsky, V. S. (2021). Assessment of Human Gait Parameters Based on Accelerometry. Biomedical Engineering, 55(2), 92-96. https://doi.org/10.1007/s10527-021-10078-y

Ferrazzoli, D., Ortelli, P., Iansek, R., \& Volpe, D. (2022). Rehabilitation in movement disorders: From basic mechanisms to clinical strategies. Handb Clin Neurol, 184, 341-355. https://doi.org/10.1016/B978-0-12-819410-2.00019-9.

Filho, M. C. D. M., \& Santos, C. A. D. (2008). Marcha na paralisia cerebral. In L. F. Fonseca \& C. L. A. Lima (Eds.), Paralisia Cerebral: neurologia, ortopedia e reabilitação (p. 658). MedBook.

G.Feldman, A., F.Levi, M., Garofolini, A., Piscitelli, D., \& Zhang, L. (2021). Central pattern generator and human locomotion in the context of referent control of motor actions. Clinical Neurophysiology, 132(11), 2870-2889. https://doi.org/https://doi.org/10.1016/j.clinph.2021.08.016

Hebert, S., Xavier, R., Pardini, A. G., \& Barros Filho, T. E. P. (2003). Ortopedia e traumatologia: princípios e prática (3rd ed.). Artmed.

Jun, K., Lee, Y., Lee, S., Lee, D.-W., \& Kim, M. S. (2020). Pathological Gait Classification Using Kinect v2 and Gated Recurrent Neural Networks. IEEE Access, 139881-139891. https://doi.org/10.1109/ACCESS.2020.3013029

Kwon, J. Y., Chang, H. J., Lee, J. Y., Ha, Y., Lee, P. K., \& Kim, Y. H. (2011). Effects of Hippotherapy on Gait Parameters in Children With Bilateral Spastic 
Cerebral Palsy. Archives of Physical Medicine and Rehabilitation, 9(2), 774-779.

Magee, D. J. (2005). Avaliação Muscuesquelética. Manole.

Matsuno, V. M., Camargo, M. R., Palma, G. C., \& Alveno, D. . (2010). Análise do uso de suporte parcial de peso corporal em esteira e em piso fixo durante o andar de crianças com paralisia cerebral. Revista Brasileira de Fisioterapia, 14, 404-410.

Mundt, M., Thomsen, W., Witter, T., \& Koeppe, A. (2021). Prediction of lower limb joint angles and moments during gait using artificial neural networks. Medical \& Biological Engineering \& Computing, 58(1), 211-225. https://doi.org/10.1007/s11517-019-02061-3

O’Sullivan, S. ., \& Schmitz, T. J. (2010). Fisioterapia: avaliação e tratamento. Manole.

Peixoto, M. V. da S., Duque, A. M., Santos, A. D. dos, Lima, S. V. M. A., Ribeiro, C. J. N., Voci, S. M., Carvalho, S. de, \& Nunes, M. A. P. (2021). Risk Factors for Cerebral Palsy in Brazilian Children: A Case-Control Study. Research, Society and Development, 10(5), 1-10. https://doi.org/https://doi.org/10.33448/rsd-v10i5.15075

Perry, J. (2005). Análise da marcha: marcha patológica. Manole.

Peterson, M. D., \& Hurvitz, E. A. (2021). Cerebral Palsy Grows Up. Mayo Clin Proc, 96(6), 1404-1406. https://doi.org/https://doi.org/10.1016/j.mayocp.2020.10.006

Prosser, L. A., Lauer, R. T., Vansant, A. F., Barbe, M. F., \& Lee, S. C. K. (2010). Variability and symmetry of gait in early walkers with and without bilateral cerebral palsy. Gait \& Posture, 31, 522-526.

Sorsdahl, A. B., Moe-Nilssen, R., \& Strand, L. (2008). Test-retest reliability of spatial and temporal gait parameters in children with cerebral palsy as measured by an electronic walkway. Gait \& Posture, 27(1), 43-50.

Stolze, H., Kuhtz-Buchbeck, J. P., Mondwurf, C., Johnk, K., \& Firege, L. (1998). Retest reliability of spatiotemporal gait parameters in children and adults. Gait \& Posture, 7(2), 125-130.

Stolze, H., Kuhtz-buschbeck, J. P., Mondwurf, C., Boczek-Funcke, A., Johnk, K., \& Keuschl, G. (1997). Gait analysis during treadmill and overground locomotion in children and adults. Electroencephalography and Clinical Neurophysiology, 105, 490-497.

Sutherland, D. H., \& Valencia, F. (1992). Pediatric Gait - normal and anormal development. In J. C. Drenann (Ed.), The Child's foot and ankle (pp. 19-35). Raven Press.

Thompson, W. R., \& Vanlandewijck, Y. C. (2020). Perspectives on research conducted at the Paralympic Games. Disability and Rehabilitation, 1-13. https://doi.org/https://doi.org/10.1080/09638288.2020.1849427

Tweedy, S. M., \& Bourke, J. (2009). Minimum disability criteria for wheelchair racing, running and jumping. In S. M. Tweedy \& J. Bourke (Eds.), IPC Athletics Classification Project for Physical Impairments: Final Report- Stage1. IPC Athletics.

Zonta, M. B., Ramalho, A., Camargo, R. M. R., Dias, F. H., \& Santos, L. H. C. (2010). Two-dimensional analysis of gait asymmetry in spastic hemiplegia. Einstein, 8(3), 343-349. 